\title{
Article \\ A Redesign Methodology to Improve the Performance of a Thermal Energy Storage with Phase Change Materials: A Numerical Approach
}

\author{
Itamar A. Harris Bernal 1,2 ${ }^{\mathbb{D}}$, Arthur M. James Rivas 1,2,*iD, María De Los A. Ortega Del Rosario 1,2 \\ and M. Ziad Saghir ${ }^{3}(\mathbb{D}$ \\ 1 Department of Mechanical Engineering, Universidad Tecnológica de Panamá, El Dorado, \\ Ciudad de Panamá 0819-07289, Panama; itamar.harris@utp.ac.pa (I.A.H.B.); \\ maria.ortega@utp.ac.pa (M.D.L.A.O.D.R.) \\ 2 Research Group-Iniciativa de Integración de Tecnologías para el Desarrollo de Soluciones \\ Ingenieriles (I2TEDSI), Universidad Tecnológica de Panamá, El Dorado, \\ Ciudad de Panamá 0819-07289, Panama \\ 3 Mechanical and Industrial Engineering Department, Ryerson University, Toronto, ON M5B 2K3, Canada; \\ zsaghir@ryerson.ca \\ * Correspondence: arthur.james@utp.ac.pa
}

check for updates

Citation: Harris Bernal, I.A.; James Rivas, A.M.; Ortega Del Rosario, M.D.L.A.; Saghir, M.Z. A Redesign Methodology to Improve the Performance of a Thermal Energy Storage with Phase Change Materials: A Numerical Approach. Energies 2022, 15, 960. https://doi.org/ $10.3390 /$ en15030960

Academic Editor: Pedro Dinis Gaspar

Received: 13 December 2021

Accepted: 18 January 2022

Published: 28 January 2022

Publisher's Note: MDPI stays neutral with regard to jurisdictional claims in published maps and institutional affiliations.

Copyright: (c) 2022 by the authors. Licensee MDPI, Basel, Switzerland. This article is an open access article distributed under the terms and conditions of the Creative Commons Attribution (CC BY) license (https:/ / creativecommons.org/licenses/by/ $4.0 /)$.

\begin{abstract}
In recent years, phase change materials (PCMs) have been presented as a suitable alternative for thermal energy storage (TES) systems for solar water heater (SWH) applications. However, PCMs' low thermal conductivity and the high dependence on external conditions are the main challenges during the design of TES systems with PCMs. Design actions to improve the performance of the TES systems are crucial to achieve the necessary stored/released thermal energy and guarantee the all-day operation of SWHs under specific system requirements. In this study, a TES with PCM in the configuration of a heat exchanger was redesigned, focused on achieving two main targets: an outlet water temperature over $43^{\circ} \mathrm{C}$ during discharging time $(15 \mathrm{~h})$ and efficiency over $60 \%$ to supply the hot water demand of two families $(400 \mathrm{~L})$. A four-step redesign methodology was proposed and implemented through numerical simulations to address this aim. It was concluded that the type, encapsulation shape, and amount of PCM slightly impacted the system's performance; however, selecting a suitable sensible heat storage material had the highest impact on meeting the system's targets. The redesigned TES reached 15 operating hours with a minimum outlet water temperature of $45.30{ }^{\circ} \mathrm{C}$ and efficiency of $76.08 \%$.
\end{abstract}

Keywords: solar water heater; thermal energy storage; phase change materials; redesign methodology; numerical simulations; sensitivity analysis; performance

\section{Introduction}

The continuous growth of the world population and industries has caused an increase in energy consumption [1]. In this context, the conventional energy sources based on fossil fuels and their derivatives have highly contributed to global warming, climate change, and air pollution [2]. Exploiting nonconventional renewable energy sources has been considered a potential alternative to overcome these problems [3]. However, these energy sources present fluctuations in their availability, and auxiliary systems have been required to achieve an all-day energy supply [4].

Thermal energy storage (TES) systems have been developed for solar water heating applications to store thermal energy as an energy backup to reduce the impact of energy fluctuations. TES systems collect thermal energy during high solar radiation hours, and then the stored energy preheats water during periods of high demand when low or no radiation is available. Therefore, TES systems can overcome the difference between the hot water demand and availability [5]. 
Latent heat storage with phase change materials (PCMs) in TES systems has been considered a suitable technique to help SWHs to provide the demand for hot water and improve their performance and autonomy [6,7]. PCMs can reduce the dependence on auxiliary heaters powered by conventional energy sources and increase the operating hours of the hot water supply during low solar radiation hours or nighttime demand [8].

PCMs in TES systems for SWHs absorb thermal energy during high solar radiation while changing their thermodynamic phase from solid to liquid. During this phase transition, the amount of thermal energy stored in PCMs oscillates between 125 and $200 \mathrm{~kJ} / \mathrm{dm}^{3}$ for organic PCMs, and between 200 and $400 \mathrm{~kJ} / \mathrm{dm}^{3}$ for salt hydrates, which are inorganic PCMs [9]. As a result, a well-designed TES system with PCMs as a thermal energy battery for a SWH can achieve a higher energy storage density at a lower and more stable storage temperature than a conventional $\mathrm{SWH}$, and it can provide compact storage and better efficiencies over the long-term operation of the system [10].

Within a SWH, different locations for the TES system with PCMs have been proposed in previous studies [11-14]. The typical configurations include PCMs placed in four locations: within the solar thermal collector [11], in a coupled PCM module between the collector and the water storage tank [15], within the water storage tank [16], and in a heat exchanger in a tankless configuration [10].

Several experimental and numerical works have been developed to evaluate the performance of different proposals of TES with PCMs for SWHs [12,17,18]. Most of these studies claimed to demonstrate the positive effect of the addition of PCMs in terms of different approaches and parameters, such as the system's efficiency [14], the amount of stored energy [15], operating hours [19], and energy savings [8,20]. However, the main challenges related to the design of a TES with PCMs for SWHs have been the low thermal conductivity of the PCMs [21] and the high dependence on external conditions to reach the melting temperature [22]. The need to improve the heat transfer rate between the PCM and the external substances has been addressed by several researchers, usually applying different enhancement techniques, such as fins [23], nanofluids [24], and nanoparticles [25]. Their works have focused on improving thermal stability and finding a higher thermal energy retain/release rate $[26,27]$.

This article presents a new approach for improving the performance of an existing TES with PCM, with the aim of $15 \mathrm{~h}$ of thermal energy discharge achieving an outlet water temperature over $43^{\circ} \mathrm{C}$ and efficiency over $60 \%$ to supply the hot water demand of two families $(400 \mathrm{~L})$. To tackle this aim, a redesign methodology was proposed based on identifying improvement opportunities after analyzing the advantages and disadvantages of a reference system. This proposal includes applying a multi-criteria decision-making method for PCM selection, PCM encapsulation shape evaluation, and the PCM load within the TES. In addition, a sensitivity analysis was performed to determine the effect of the sensible heat storage material's properties in taking advantage of the PCM properties. All these evaluations were applied to the heat exchanger as TES with PCMs proposed and studied by Bayomy et al. [13]. The proposed methodology is presented in four steps applied by several numerical simulations using COMSOL Multiphysics 5.6 to obtain curves and figures that show the effect of the changes related to each step.

\section{Description of the Thermal Energy Storage System for Redesign}

After a wide range of experimental and numerical studies related to TES with PCM for SWHs, one of the major tasks is defining the most suitable model or configuration. It is challenging to compare the proposed configurations found in the literature because researchers have considered different flow rates, heat storage methods, solar collector sizes, materials, enhancement methods, and more. Moreover, not all parameters can be measured and compared based on performance [7]. However, heat exchangers in a tankless configuration pose no risk of cross-contamination with PCM and no risk of growth of legionella bacteria in hot drinking water during its operation, if compared to other typical configurations $[7,10]$. 
In this numerical study, a heat exchanger in a tankless configuration based on the research by Bayomy et al. [13] was selected as a reference system to be redesigned. In addition to the benefits of this configuration in terms of health factors [7], it also provides good internal space to test different amounts, encapsulation shapes, and topology of the PCM in a redesign process. The proposed system only allows the hot drinking water to pass through a coil. A combination of water and PCM cylinders was placed outside the coil to store thermal energy, as presented in Figure 1.

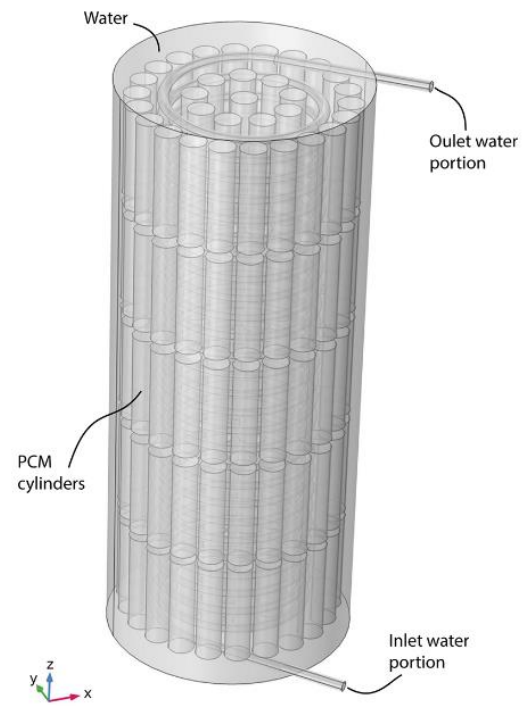

Figure 1. A thermal energy storage system with PCM by Bayomy et al. [13].

In their study, Bayomy et al. mainly focused on analyzing the stored and released heat in the thermal energy storage tank. The dependence of the efficiency and the temperature of the hot water was evaluated according to the demand for hot water corresponding to a different number of families. The heat exchanger was composed of a $0.28 \mathrm{~m}$ diameter coil with a pipe diameter of $0.02 \mathrm{~m}$. The tank had a height and diameter of $1.15 \mathrm{~m}$ and $0.46 \mathrm{~m}$, respectively. In addition, this TES had 32 cylindrical PCM rods per row, with a total of five rows. The PCM was encapsulated into cylinders of $0.2 \mathrm{~m}$ height and $0.05 \mathrm{~m}$ diameter. $\mathrm{N}$-eicosane was used as PCM, and its properties are presented in Table 1.

Table 1. N-eicosane thermal properties [13].

\begin{tabular}{|c|c|c|}
\hline N-Eicosane & Solid Phase & Liquid Phase \\
\hline Melting point $\left({ }^{\circ} \mathrm{C}\right)$ & \multicolumn{2}{|c|}{36.4} \\
\hline Latent heat $(\mathrm{kJ} / \mathrm{kg})$ & \multicolumn{2}{|c|}{247.3} \\
\hline Thermal conductivity $(\mathrm{W} / \mathrm{m} \cdot \mathrm{K})$ & 0.35 & 0.15 \\
\hline Specific Heat $(\mathrm{kJ} / \mathrm{kg} \cdot \mathrm{K})$ & 2.1360 & 2.1336 \\
\hline Density $\left(\mathrm{kg} / \mathrm{m}^{3}\right)$ & 856 & 778 \\
\hline
\end{tabular}

As thermal boundary conditions, an inlet water temperature of $50{ }^{\circ} \mathrm{C}$ was considered during charging time $(9 \mathrm{~h})$ and $20^{\circ} \mathrm{C}$ during discharging time $(15 \mathrm{~h})$. Moreover, the tank was insulated.

Fluid flow boundary conditions were also considered for the inlet water velocity, in addition to a no-slip condition in the rest of the walls and the outlet. The velocity was set during the charging period to represent fluid flows of 2,3 , and $4 \mathrm{~L} / \mathrm{min}$. Typical domestic hot water demand profiles were taken during the discharging period to set the expected water flow to supply the demand of one (200 L), two (400 L), three (600 L), and four $(800 \mathrm{~L})$ families. Bayomy et al. analyzed the performance depending on the number of 
families considering the hot water draw profiles for domestic hot water systems according to ASHRAE Standard 90.2 [28].

Their numerical simulations with different flow rates demonstrated the TES capacity to maintain the outlet temperature between 27 and $46{ }^{\circ} \mathrm{C}$. The stored energy increased with the increment in the fluid flow. Moreover, the efficiency increased with the increment in the hot water supply flow rate between $35 \%$ to $39 \%$, and with the increment of family demand, from $35 \%$ for one family to $82 \%$ for four families for the hot water flow of $2 \mathrm{~L} / \mathrm{min}$.

An assumption made in the reference study was that the presence of PCM in the TES was positive for the system's performance. No simulations were run in the case without PCM to verify this aspect. In addition, the type, amount, and encapsulation shape of the PCM were assumed without considering other possible alternatives. This was also reflected in the selection of water as the sensible heat storage substance.

The approach carried out in the reference study was to achieve the highest efficiency in harnessing the most considerable amount of energy stored in the PCMs without defined targets in terms of the minimum outlet water temperature and minimum efficiency. However, it is observed in Figure 2 that the greater the number of families, the more noticeable the decrease in temperature during discharging time.

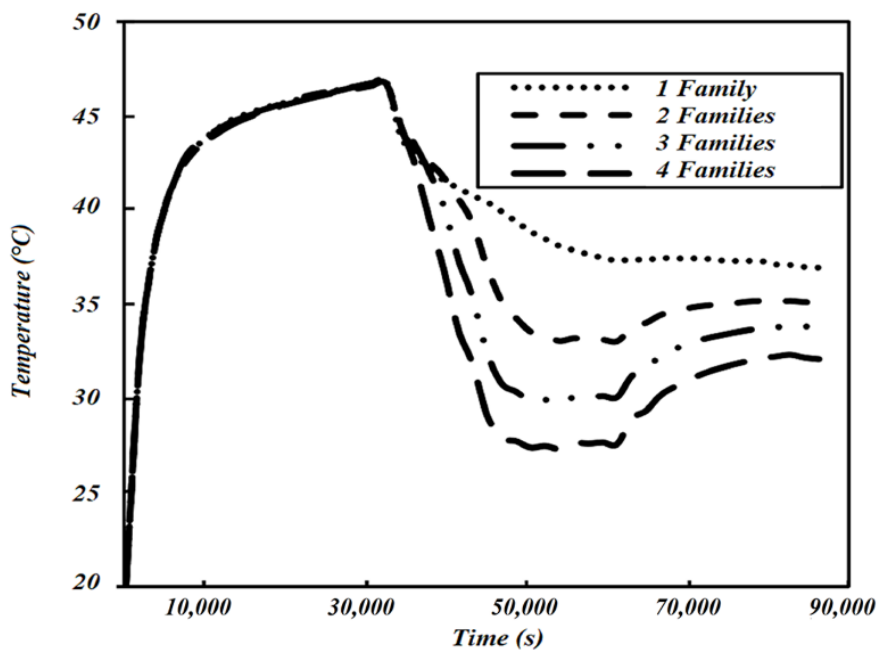

Figure 2. Hot water temperature vs. time and the number of families [13].

The American Society of Mechanical Engineers (ASME) recommends a minimum hot water temperature of $43^{\circ} \mathrm{C}$ for domestic applications [29]. Although the reference work did not emphasize a minimum temperature requirement, Figure 2 shows that the reference TES with PCM does not reach temperatures above $43{ }^{\circ} \mathrm{C}$ during the $15 \mathrm{~h}$ of discharge for any of the demand conditions considered, and the most efficient case when meeting the highest demand $(800 \mathrm{~L})$ leads to lower temperatures.

The above weaknesses found in the reference TES with PCM led to four improvement opportunities to carry out its redesign as discussed in the next section.

\section{Improvement Opportunities for a Redesign}

During the identification of improvement opportunities for a redesign, the tank and coil dimensions were unchanged. Additionally, the tank walls were assumed insulated. After these considerations, the present study focused on the improvement opportunities identified as follows:

- In the reference study, the TES with PCM was not compared to the case without PCM (WP-TES) to evaluate whether the PCM improves the performance. The presence of PCM does not guarantee improvement in the system's performance $[8,30,31]$. The design should be evaluated for the case of only sensible heat storage material to define the current needs to enhance the performance with PCMs. 
- The technical requirements are crucial when selecting a PCM for a specific application [32]. Therefore, it is necessary to set a minimum hot water outlet temperature goal based on the technical requirements and select a new PCM with a melting temperature near the minimum target temperature of the hot water according to the literature [19].

- In the reference study, neither of the flow rates selected could completely charge the PCM during the charging period $(9 \mathrm{~h})$. In addition, the PCM capsules were not completely solidified after any discharging period, which suggests the need to reevaluate the PCM amount [33] and encapsulation shape [34].

- The effect of the sensible heat storage material in the TES system is crucial because it consists of a well-balanced combination of latent and sensible heat storage materials [35]. Therefore, an improvement option consists of evaluating if water is the best option as a sensible heat storage material, and selecting another material on the contrary case [36]. The selected TES with PCM configuration allows considering a sensible storage material other than water due to the non-existence of contact between the hot drinking water and the TES materials [37].

This study mainly focused on improvement options related to the type, shape, and amount of sensible and latent heat storage materials. More complex enhancement options, such as fins, nanofluids, and nanoparticles to enhance heat transfer, were not considered. Thus, the results after implementing the four improvement opportunities previously identified for the redesign can indicate the need, or not, for these complex enhancement options.

\section{Methodology}

A four-step redesign methodology was proposed based on the four improvement opportunities previously defined. This included the evaluation of operating conditions and new design targets, the comparison between the reference TES with and without PCM (step 1), the PCM selection through multi-criteria decision-making methods (step 2), the evaluation of the amount and shape of the PCM (step 3), and sensitivity analysis of the effect of the sensible heat storage material on the PCM performance (step 4). Every step was implemented through numerical simulations in COMSOL Multiphysics 5.6 (Burlington, MA, USA).

\subsection{Step 1: Definition of Current Operating Conditions and Comparison of the Reference TES with} the TES without PCM

A brief review of the considered reference system's operating conditions and targets is shown in Table 2. It can be observed that the original TES did not include a minimum design temperature after discharging time $(15 \mathrm{~h})$ and a minimum efficiency target. These parameters were included as new targets during this redesign process. The minimum temperature after discharging time was set based on the minimum water temperature recommended by ASME for hot water domestic applications of $43{ }^{\circ} \mathrm{C}$ [29].

Table 2. System parameters and targets according to the context.

\begin{tabular}{ccc}
\hline Operating Conditions and Targets & Reference TES & Redesigned TES \\
\hline Inlet hot water temperature during & $50{ }^{\circ} \mathrm{C}$ & $57{ }^{\circ} \mathrm{C}$ \\
charging time & & \\
Inlet cold water temperature during & $20{ }^{\circ} \mathrm{C}$ & $27{ }^{\circ} \mathrm{C}$ \\
discharging time) & $9 \mathrm{~h}$ & $9 \mathrm{~h}$ \\
Charging time & $15 \mathrm{~h}$ & $15 \mathrm{~h}$ \\
Discharging time & Does not apply & $43{ }^{\circ} \mathrm{C}$ \\
Minimum temperature during & $1,2,3$ and 4 & 2 \\
discharging time (15 h) & Not defined & $60 \%$ \\
Number of families & &
\end{tabular}


In addition, the present redesign considers the possible application of the TES with PCM under the tropical climate of Panama [38]. Based on this aspect, the inlet cold water temperature was set as $27^{\circ} \mathrm{C}$, the estimated mean domestic water temperature in the Republic of Panama [39]. The design inlet hot water temperature was selected to maintain the same difference of $30^{\circ} \mathrm{C}$ between hot and cold inlet water temperatures as in the reference study. Furthermore, this redesign aims to provide hot water for 2 families (400 L) only, instead of 1,2,3, and 4 families as in the reference study.

Based on the operating conditions and the new design targets for the TES (Table 2), the thermal boundary conditions for the numerical simulations were a constant water inlet temperature of $57^{\circ} \mathrm{C}$ during charging time $(9 \mathrm{~h})$, and $27^{\circ} \mathrm{C}$ during discharging time $(15 \mathrm{~h})$, to complete an all-day operation. In addition, the tank was considered insulated. The fluid flow boundary conditions were the inlet water velocity profile to represent a fluid flow of $2 \mathrm{~L} / \mathrm{min}$ and hot water demand of $400 \mathrm{~L}$ according to ASHRAE Standard 90.2 [28] (see Figure 3). The no-slip condition was considered in the rest of the walls and the outlet.

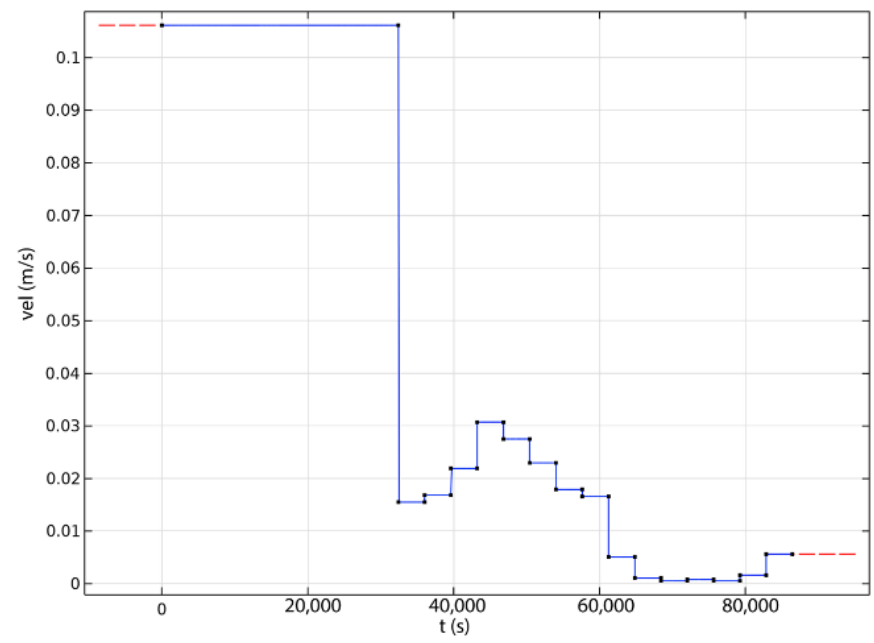

Figure 3. Water velocity in the coil for the demand of 2 families (400 L) vs. time.

In the simulations for the case of the TES without PCM, the PCM cylinders were replaced by water. The thermal and fluid flow boundary conditions were the same as the case with PCM.

\subsection{Step 2: Selection of New PCM}

The literature suggests the PCM melting temperature should be close to the minimum desired hot water temperature during discharging time [19], which is $43^{\circ} \mathrm{C}$ for dwelling hot water application [29].

Three possible organic PCMs with melting temperatures between $43-45{ }^{\circ} \mathrm{C}$ were considered for selection. Table 3 presents the main properties of these organic PCMs found in the literature.

Table 3. Organic PCMs for SWHs identified in the literature.

\begin{tabular}{|c|c|c|c|c|c|c|c|c|}
\hline \multirow[t]{2}{*}{ Material } & \multicolumn{2}{|c|}{$\begin{array}{l}\text { A. Thermal } \\
\text { Conductivity } \\
(\mathrm{W} / \mathrm{m} \cdot \mathrm{K})\end{array}$} & \multicolumn{2}{|c|}{$\begin{array}{l}\text { B. Specific Heat } \\
(\mathrm{kJ} / \mathrm{kg} \cdot \mathrm{K})\end{array}$} & \multirow{2}{*}{$\begin{array}{c}\text { C. Latent } \\
\text { Heat } \\
(\mathrm{kJ} / \mathrm{kg})\end{array}$} & \multirow{2}{*}{$\begin{array}{c}\text { D. Melting } \\
\text { Temperature } \\
\left({ }^{\circ} \mathrm{C}\right)\end{array}$} & \multicolumn{2}{|c|}{$\begin{array}{l}\text { E. Density } \\
\left(\mathrm{kg} / \mathrm{m}^{3}\right)\end{array}$} \\
\hline & Liquid & Solid & Liquid & Solid & & & Liquid & Solid \\
\hline 1. Lauric Acid & 0.15 & 0.37 & 2.154 & 2.1416 & 182.92 & 43.9 & 870 & 1.007 \\
\hline 2. RT44 [43] & 0.2 & 0.2 & 2 & 2 & 250 & 43 & 700 & 800 \\
\hline 3. АTP 43 [44] & 0.2 & 0.2 & 2 & 2 & 265 & 43 & 760 & 780 \\
\hline
\end{tabular}


The PCM selection is a crucial task that mainly depends on the melting temperature and thermal conductivity. However, different physical, chemical, and economic properties impact the selection, and, in some cases, these properties may conflict with each other when looking for selection criteria that seek the best results for each of them. No PCM contains all of the desired properties [21]; nonetheless, the selection during the design process can consider multiple criteria, even in conflict, through the application of multi-criteria decision-making methods (MCDM) [45].

In this step, VIKOR (Vise Kriterijumska Optimizacija Kompromisno Resenje) [45] and COPRAS (complex proportional assessment) [46] methods were applied for new PCM selection considering the properties identified in Table 3 as criteria for selection. The entropy method was used to determine the weights of criteria importance. The application of these MCDM provided a classification of the alternatives using the compromised weight of the entropy method [47].

VIKOR and COPRAS revealed lauric acid (LA) as the most promising among the materials considered. Next, the system's behavior with LA instead of n-eicosane (N-E) was simulated to verify if LA allowed the system to meet the targets for the redesigned TES.

\subsection{Step 3: Evaluation of Geometry and Size of PCM Encapsulation}

Several researchers have demonstrated that the encapsulation geometry can impact the heat transfer between PCM and the external heat transfer fluid $[34,48,49]$. The related studies on the encapsulation geometry effect have focused on PCM capsules or prisms under constant temperature boundary conditions [34]. However, through numerical simulations, it is possible to select the encapsulation geometry based on the TES system response to transient temperature boundary conditions.

Three encapsulation shapes were evaluated: drop-shaped, triangular, and circular cross-section prisms. The circular cross-section prisms were cylinders, the same shape as in the reference TES. In all cases, the cross-section area was designed to maintain the same PCM volume per prism, as shown in Figure 4. The prism's height was fixed as $200 \mathrm{~mm}$.
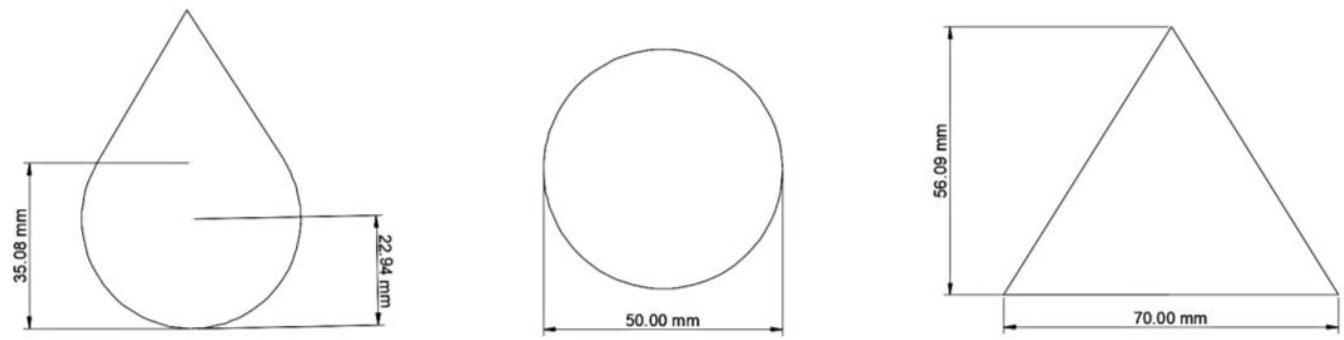

Figure 4. Cross-section shapes for shape evaluation.

The numerical simulations of the charging time of these different cross-section-shaped prisms were run to compare their performances. A cut-plane was defined to obtain molten phase fraction profiles in the middle of the TES at the end of the charging time.

\subsection{Step 4: Evaluation of Sensible Heat Storage Substance}

The sensible heat storage capacity quantifies the potential of a material to store thermal energy while changing its temperature. An effective sensible energy storage material will have a high sensible heat storage capacity; however, this is not enough to make a selection. After storing thermal energy, the material should release it satisfactorily. The main property related to this adequate thermal energy release rate is thermal conductivity. Water is an example of a material with a high energy density but low thermal conductivity. Due to this fact, several studies have been undertaken to increase the thermal conductivity of water and other substances by including nano-conductive particles in the production of "nanofluids" [24]. The efforts to also increase the thermal conductivity of PCM have been 
previously reviewed [50]. However, the thermal conductivity improvements tend to be difficult and limited [51].

A sensitivity analysis through several numerical simulations was performed to quantify the effect of the thermal conductivity of the sensible heat storage substance on the TES performance, maintaining the same sensible heat storage capacity as water $\left(\mathrm{C}_{\mathrm{pw}}=4169.45 \mathrm{~kJ} / \mathrm{m}^{3} \cdot \mathrm{K}\right.$ at $\left.25^{\circ} \mathrm{C}\right)$ [52]. Based on the sensitivity analysis results, a sensible heat storage material with suitable characteristics for the application was selected. Then numerical simulations of the TES with only this material, and with PCM, were performed.

The proposed four-step methodology can be finally summarized in the flow chart illustrated in Figure 5.

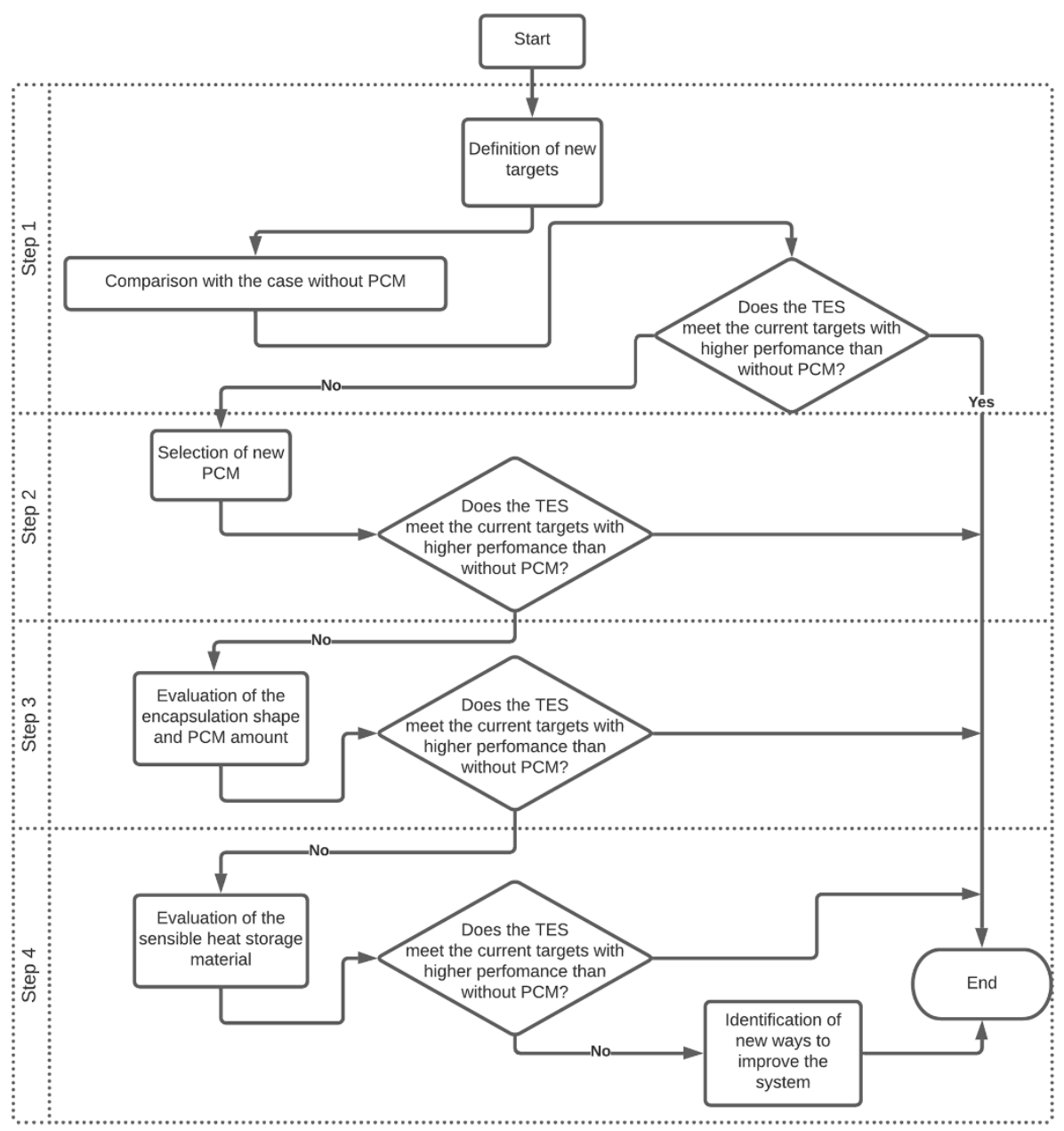

Figure 5. Proposed redesign methodology flow chart.

\section{Numerical Model}

The implementation of the proposed redesign methodology was performed through numerical simulations in COMSOL Multiphysics 5.6 (Burlington, MA, USA). The solutions of these simulations were derived considering the following assumptions:

- The liquid phase is a Newtonian and incompressible fluid [13].

- The flow in the coil is laminar [13].

- The natural convection in the movement and behavior during the melting process is neglected for simplicity [15].

- The PCM encapsulation material does not affect the heat transfer rate between the sensible and latent heat storage substances, meaning it is considered to be entirely thermally conductive [15]. 
- The volume of the PCM does not experience changes during the phase transition [15].

- A stagnated substance surrounds the PCM prisms, and its velocity is zero [15].

- The velocity of PCM during the solid phase is zero even when surrounded by liquid [15].

- PCM is homogeneous and isotropic [34].

- The system is assumed stationary [53].

- $\quad$ PCM melting and solidifying temperatures are the same [54].

As depicted in Figure 2, the TES with PCM has three main components to model: the macro-encapsulated PCM, water flow into the coil, and a stagnated external substance for sensible heat storage. Every component was modeled based on transport phenomena equations [53]. These equations were solved by COMSOL Multiphysics 5.6 based on finite element formulation (FEM).

The energy equation was used to model the heat transfer in the macro-encapsulated PCM [13]. In this analysis, the specific heat and the density were modeled through the apparent capacity method [8,55]. The Navier Stokes equations were applied to model the momentum transport, continuity, and energy in the water flow into the coil [13]. The external substance for sensible heat storage is considered to be stagnated independently of its phase (liquid or solid). In this substance, only the heat transfer effect is considered and given by the energy equation [13]. In addition, the heat transfer mechanism is conduction between the sensible heat storage substance and the PCM. The tank is considered wholly insulated, and it limits the heat transfer to internal substances.

The numerical model was verified to assess the dependence of the solutions on the grid size and the time-stepping. First, three grid sizes were examined: 405,968, 1,864,149, and 4,173,726. The model with 405,968 elements offered the shortest computation time with negligible variation in results compared to those obtained with finer grids. Therefore, due to the considerably smaller number of elements and the little variation with respect to the other options, 405,968 elements was selected as the grid size to evaluate the system under different conditions. Then, the effect of the time step in the solutions with the selected number of elements was evaluated considering three time-step sizes: $1 \mathrm{~s}, 0.5 \mathrm{~s}$, and $0.2 \mathrm{~s}$. The difference between the results was negligible, which suggests that the results were independent of the time step. Therefore the time-dependent numerical simulations for every step were simulated with time steps taken by the solver using an adaptive timestepping scheme that allows the software to automatically adjust the time-step size to maintain a chosen relative tolerance [56]. In this study, the relative tolerance was set at 0.001 and the time-stepping method was the Backward Differentiation Formula (BDF), which is an implicit solver that uses backward differentiation formulas [57]. The results were displayed every $1800 \mathrm{~s}$ until 86,400 s (24 h). The mesh was prepared as physics-controlled, with an average element quality of 0.6 according to the skewness quality measure [58]. The implemented boundary conditions were discussed in the previous section.

\section{Results and Discussion}

6.1. Implementation of Step 1: Definition of Current Operating Conditions and Comparison of the Reference TES with the TES without PCM

The reference (R) TES with n-eicosane as PCM was studied through numerical simulations during the entire operating time of $86,400 \mathrm{~s}(24 \mathrm{~h})$ to characterize its behavior under previous and current operating conditions presented in Table 2. In addition, the behavior of the case without PCM (WP), that is the case in which water surrounds the coil as a sensible heat storage substance, was also studied for comparison with R. Both TES systems are shown in Figure 6. The results of these first simulations are depicted in Figures 7 and 8, which present curves of water temperature vs. time for both previous (P) and current (C) inputs. 


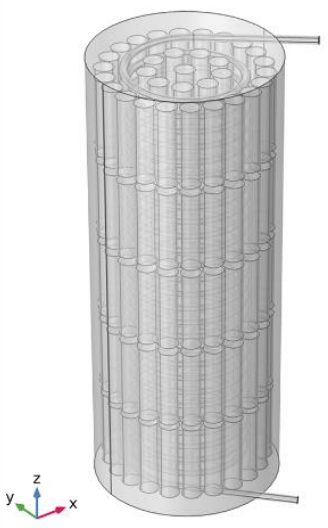

(a)

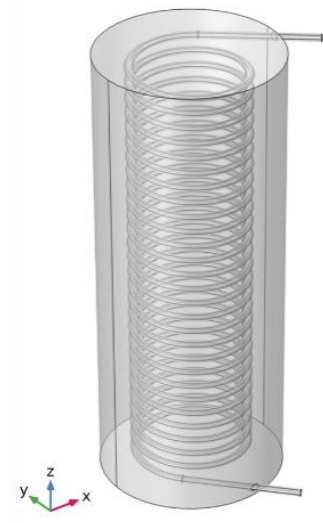

(b)

Figure 6. TES systems: (a) reference (R); (b) without PCM (WP).

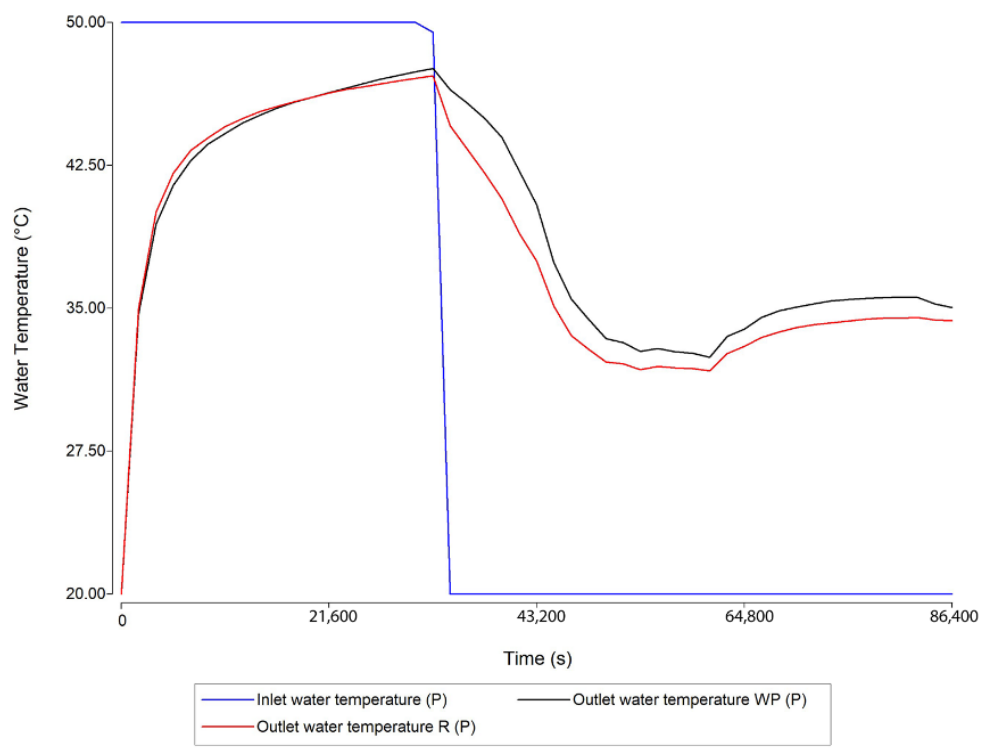

Figure 7. Variation of inlet and outlet water temperatures for the reference (R) TES and the TES without PCM (WP), under previous input $(\mathrm{P})$.

In Figure 7 it is observed that for the previous input, both TES with and without PCM presented similar charge profiles in terms of the outlet water temperatures in the coil. WP allowed a slightly higher maximum outlet water temperature $\left(46.47^{\circ} \mathrm{C}\right)$ than the obtained in $\mathrm{R}\left(44.58^{\circ} \mathrm{C}\right)$. Furthermore, during discharging time, WP allowed a $\approx 10.59 \%$ higher energy release than the case with PCM.

The current input allowed a similar charge profile, as depicted in Figure 8. Like under previous input, WP reached a higher maximum outlet water temperature $\left(52.35^{\circ} \mathrm{C}\right)$ compared to obtained by $\mathrm{R}$ after the charging time $\left(51.05^{\circ} \mathrm{C}\right)$. During discharging time, WP increased its energy release capacity compared to the case with $\mathrm{PCM}$, which was $\approx 21.71 \%$ higher. At the same time, the efficiency and the operating hours were higher in WP for both previous and current operating conditions.

Table 4 shows the comparison of some critical parameters, such as the accumulated and delivered energy during charging and discharging times, the efficiency (the delivered energy compared to the accumulated energy), maximum outlet water temperature during charging time, minimum outlet water temperature during discharging time, and the operating hours. Operating hours were defined as the total hours with an outlet water temperature higher than $43^{\circ} \mathrm{C}$, based on the minimum recommended hot water tempera- 
ture for domestic applications according to ASME [29]. These parameters were considered throughout this study.

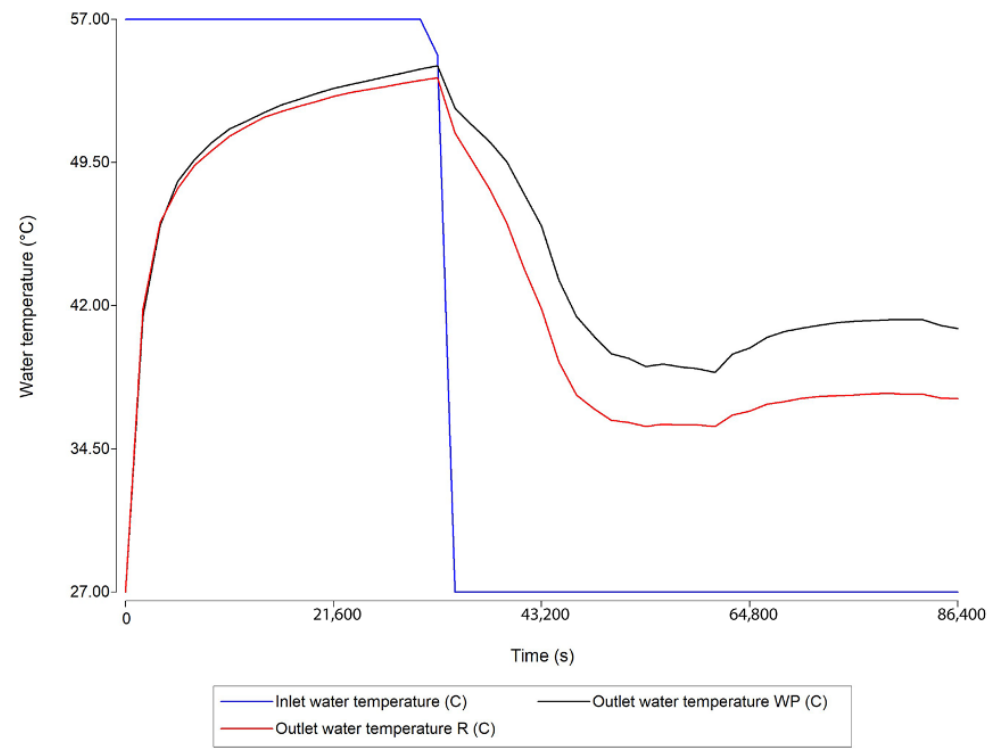

Figure 8. Variation of inlet and outlet water temperatures for the reference (R) TES and the TES without PCM (WP), under current input (C).

Table 4. Comparison of several parameters related to the reference system (R) operation with and without PCM (WP) for the previous and current operating conditions.

\begin{tabular}{|c|c|c|c|c|}
\hline \multirow{2}{*}{ Parameters } & \multicolumn{2}{|c|}{$\mathbf{R}$} & \multicolumn{2}{|c|}{ WP } \\
\hline & Previous & Current & Previous & Current \\
\hline $\begin{array}{c}\text { Accumulated energy during charging } \\
\text { time }(\mathrm{kJ})\end{array}$ & $21,438.83$ & $23,435.74$ & $21,938.15$ & $21,992.92$ \\
\hline $\begin{array}{c}\text { Delivered energy during discharging } \\
\text { time }(\mathrm{kJ})\end{array}$ & $12,319.92$ & $10,091.53$ & $13,778.93$ & $12,890.47$ \\
\hline Efficiency $(\%)$ & 57.47 & 43.06 & 62.81 & 58.61 \\
\hline $\begin{array}{l}\text { Maximum outlet water temperature } \\
\text { during charging time }\left({ }^{\circ} \mathrm{C}\right)\end{array}$ & 44.58 & 51.05 & 46.47 & 52.35 \\
\hline $\begin{array}{l}\text { Minimum outlet water temperature } \\
\text { during dicharging time }\left({ }^{\circ} \mathrm{C}\right)\end{array}$ & 34.35 & 35.68 & 35.04 & 38.51 \\
\hline $\begin{array}{l}\text { Operating hours (Outlet water } \\
\text { temperature higher than } 43^{\circ} \mathrm{C} \text { ) }\end{array}$ & 1 & 2 & 2 & 3.5 \\
\hline
\end{tabular}

Table 4 shows WP accomplished the best performance for the previous and the new operating conditions. It reaches higher outlet water temperatures during charging and discharging times, higher efficiencies, and longer operating hours. The presence of PCM did not improve the system's performance compared to WP. However, neither scenario could meet the proposed minimum outlet temperature and expected operating hours during the discharging time. Therefore, the second step, selecting a new PCM, was executed to improve the PCM's contribution to the system.

\subsection{Implementation of Step 2: Selection of a New PCM}

As previously mentioned in Section 4.2, LA was selected as the new PCM based on the multi-criteria decision-making methods VIKOR and COPRAS. Figure 9 presents the results of the numerical simulations of three configurations: the reference TES with lauric acid cylinders (LA_R), the reference TES with n-eicosane cylinders (N-E_R), and the TES without PCM (WP). These configurations were simulated under the current inlet water temperature profile as input (C). 


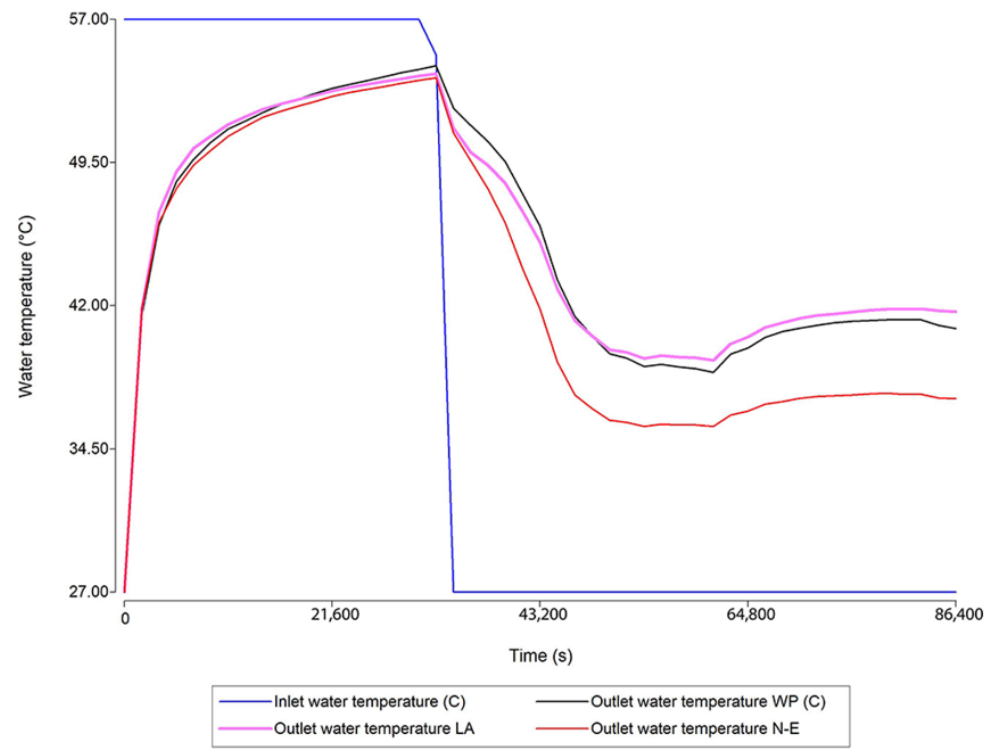

Figure 9. Inlet and outlet water temperatures vs. time for the reference TES with and without PCM, based on the operation under current input (C).

Figure 9 shows that the outlet water temperature profile in the LA_R was always higher than the profile obtained with the N-E_R. When comparing LA_R and WP outlet water temperature profiles, the latter could maintain higher temperatures during the first hours of discharge, which were the highest hot water demand hours. When the hot water demand decreased after $\approx 50,000 \mathrm{~s}$, the LA improved the outlet water temperature by approximately $1{ }^{\circ} \mathrm{C}$.

Other parameters for comparison are presented in Table 5. Although N-E_R stored more energy (approximately 9\% more), the LA_R allowed a higher energy release (approximately $26 \%$ more). Hence, the LA_R presented higher efficiency and more operational hours than the N-E_R. The differences between LA_R and WP were negligible, but the latter provided longer operating hours. Neither of the scenarios could meet the targets for the redesigned TES. Therefore, step three-evaluation of geometry and size of PCM encapsulation-is required to improve the performance of LA in the TES system.

Table 5. Comparison of several parameters related to the reference TES (R) operation with different PCMs and the TES without PCM (WP) under current input.

\begin{tabular}{cccc}
\hline Parameters & \multicolumn{2}{c}{ R } & WP \\
\cline { 2 - 3 } & N-E & LA & \\
\hline Accumulated energy during charging time $(\mathrm{kJ})$ & $23,435.74$ & $21,342.06$ & $21,992.92$ \\
Released energy during discharging time $(\mathrm{kJ})$ & $10,091.53$ & $12,749.78$ & $12,890.47$ \\
Efficiency $(\%)$ & 43.06 & 58.96 & 58.61 \\
Maximum outlet temperature during charging time $\left({ }^{\circ} \mathrm{C}\right)$ & 51.05 & 51.30 & 52.35 \\
Minimum outlet water temperature during discharging & 35.68 & 39.14 & 38.51 \\
time $\left({ }^{\circ} \mathrm{C}\right)$ & 2 & 3 & 3.5 \\
Operating hours (Outlet water temperature over $\left.43^{\circ} \mathrm{C}\right)$ & & & \\
\hline
\end{tabular}

\subsection{Implementation of Step 3: Evaluation of Geometry and Size of PCM Encapsulation}

First, the numerical simulations of the charging time for triangular and circular crosssections prisms were run to compare their performances under current input [34]. The final results of molten phase fraction profiles in a cut-plane at the middle of the TES are depicted in Figures 10 and 11. In red is the melted area, and in blue is the solid-phase area. 


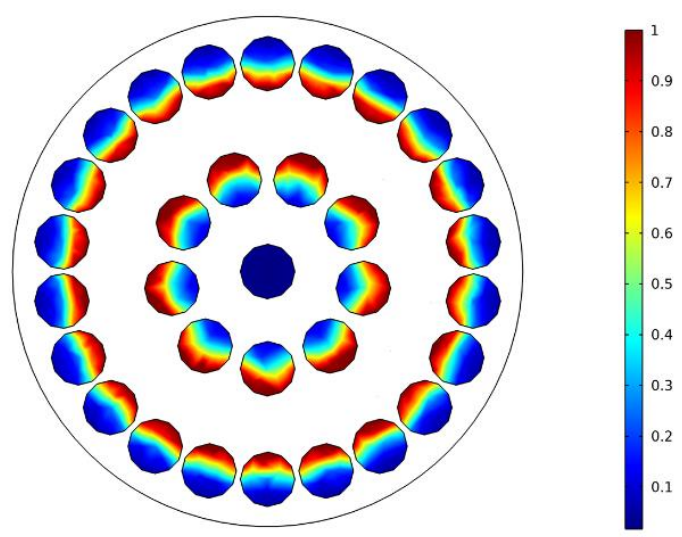

(a)

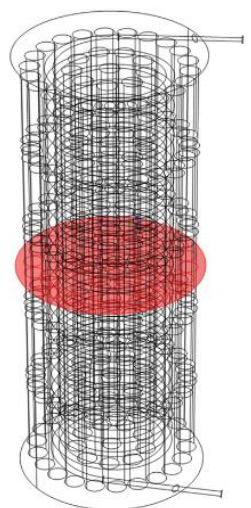

(b)

Figure 10. Phase transition in circular cross-section PCM prisms after charging time: (a) molten phase fraction in a cut plane defined in the middle of the TES ( $0-1$ from solid to liquid); (b) location of the cut plane in the TES.

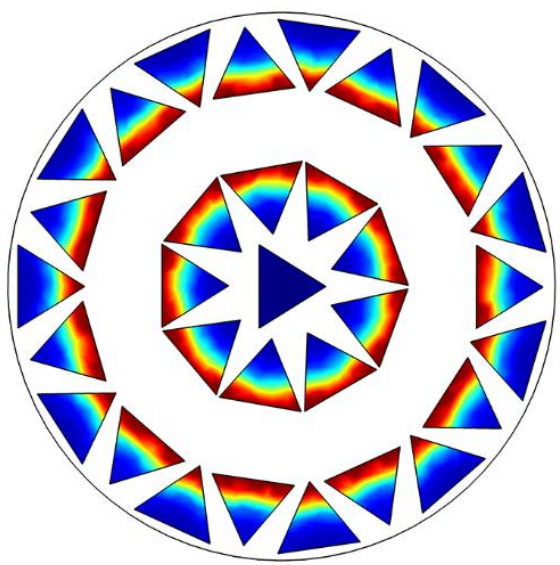

(a)

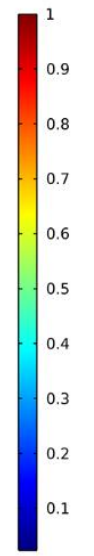

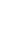

(a)

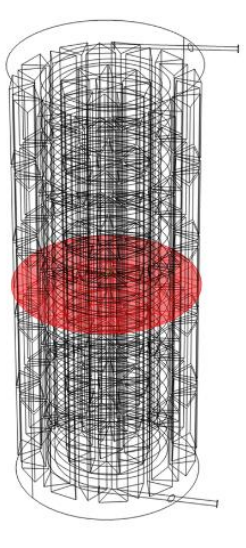

(b)

Figure 11. Phase transition in triangular cross-section PCM prisms after charging time: (a) molten phase fraction in a cut plane defined in the middle of the TES ( $0-1$ from solid to liquid); (b) location of the cut plane in the TES.

It is observed in Figures 10 and 11 that central prisms did not experience phase change due to their low proximity to the heat source, which is hot water flowing into the coil. Based on this behavior, simulations of drop-shaped and circular cross-section PCM prisms were performed without the central elements; the results for these evaluations are presented in terms of the molten phase fraction after charging period in Figures 12 and 13. 


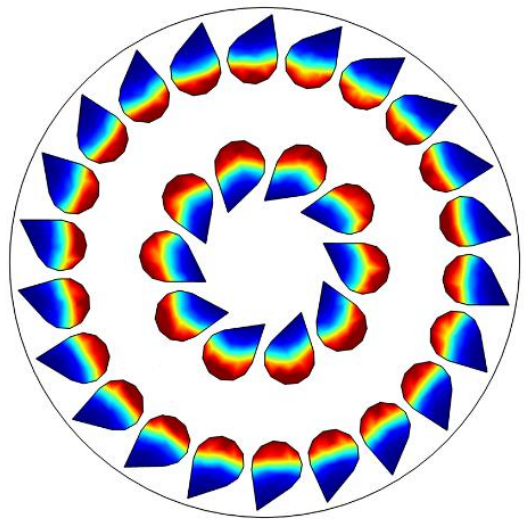

(a)

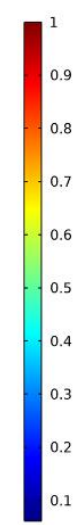

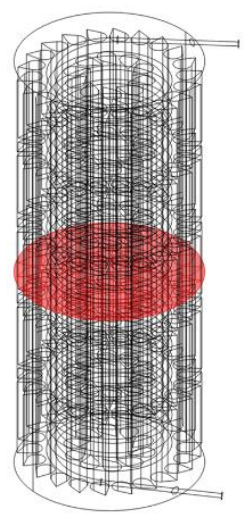

(b)

Figure 12. Phase transition in drop-shaped cross-section PCM prisms after charging time: (a) molten phase fraction in a cut plane considered in the middle of the TES ( $0-1$ from solid to liquid); (b) location of the cut plane in the TES.

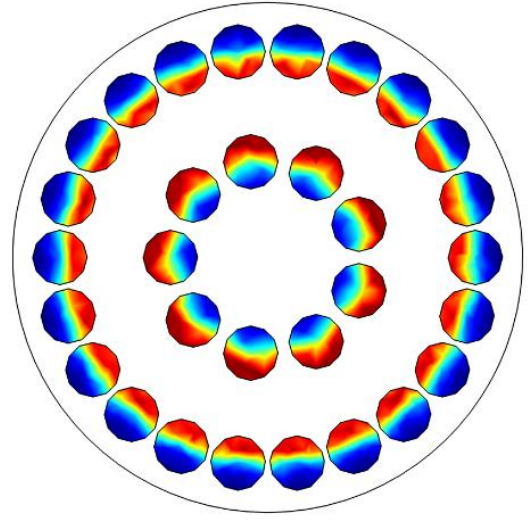

(a)

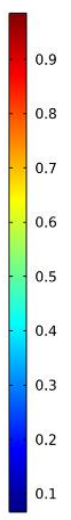

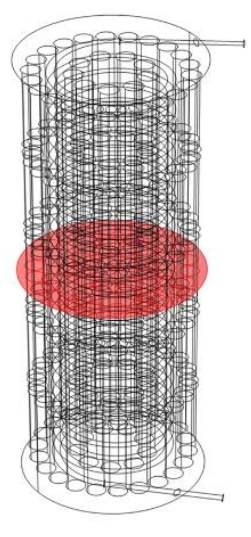

(b)

Figure 13. Phase transition in circular cross-section PCM prisms, without central prisms, after charging time: (a) molten phase fraction in a cut plane considered in the middle of the TES (0-1 from solid to liquid); (b) location of the cut plane in the TES.

Figures 12 and 13 showed no perceptible increment in the molten phase fraction compared to previous configurations, even without the central PCM prisms. However, Table 6 shows the circular cross-section PCM prisms reached the highest accumulated energy, and the $3 \%$ of PCM reduction increased the accumulated energy by almost $1 \%$ while allowing an increment in the maximum mean molten phase fraction by approximately $3 \%$.

Table 6. Comparison between main parameters for shape evaluation.

\begin{tabular}{ccccc}
\hline & Cross-Section Shapes \\
\cline { 2 - 5 } Parameter & Triangular & Drop & Circular & $\begin{array}{c}\text { Circular without Central } \\
\text { Elements (Approx. 3\% } \\
\text { Less PCM) }\end{array}$ \\
\hline $\begin{array}{c}\text { Acummulated energy } \\
\text { during charging time (kJ) } \\
\begin{array}{c}\text { Maximum mean molten } \\
\text { fraction in a cut-plane at } \\
\text { the middle of the TES (pu) }\end{array}\end{array}$ & $21,111,56$ & $21,180.21$ & $21,342.06$ & $21,527.19$ \\
\hline
\end{tabular}


Therefore, these results suggested that PCM reduction, which will not melt during charging period due to its location, increased the mean melting percentage without a high reduction in the accumulated energy. Consequently, a higher subtraction of PCM is proposed by eliminating approximately $50 \%$ of PCM that will not melt according to the results in Figure 13. Figure 14 shows the molten phase fractions after the charging time of the resulting thermal energy storage with reduced lauric acid prisms (LA-Rr).

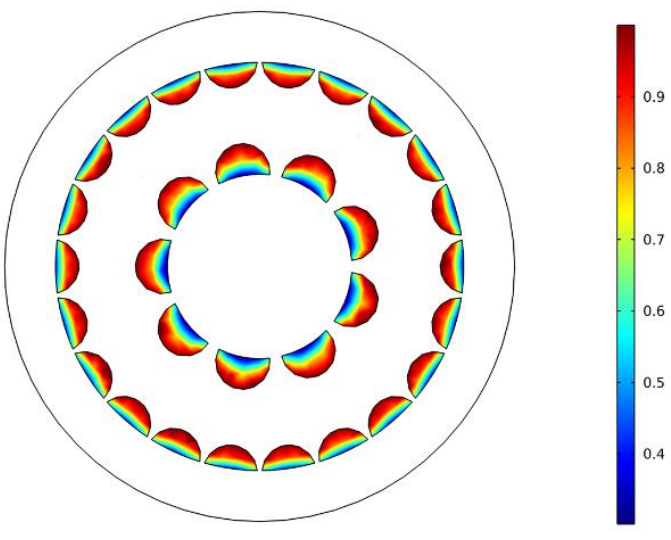

(a)

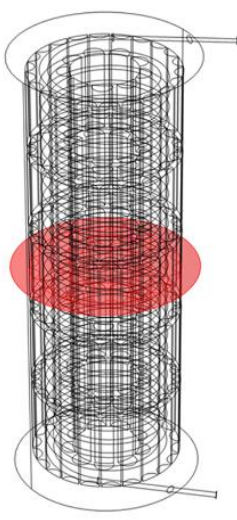

(b)

Figure 14. Phase transition in PCM reduced prisms after charging time: (a) molten phase fraction in a cut plane defined in the middle of the TES (0-1 from solid to liquid); (b) location of the cut plane in the TES.

Figure 14a shows that most of the PCM is melted in the cut plane at the middle of the TES after charging time. The proposed reduction in PCM by approximately $50 \%$ increased the amount of accumulated energy to $22,012.70 \mathrm{~kJ}$, approximately $2.5 \%$ higher than the accumulated energy in the case of the circular cross-section without central prisms. These results are attributed to the reduction in the PCM and the increase in water, which implies an increment of material with higher thermal conductivity and sensible heat storage capacity. Based on these results, the configuration of thermal energy storage with reduced lauric acid prisms (LA_R $R_{\mathrm{r}}$ ) was selected as the proposed geometry and amount of lauric acid as shown in Figure 15.

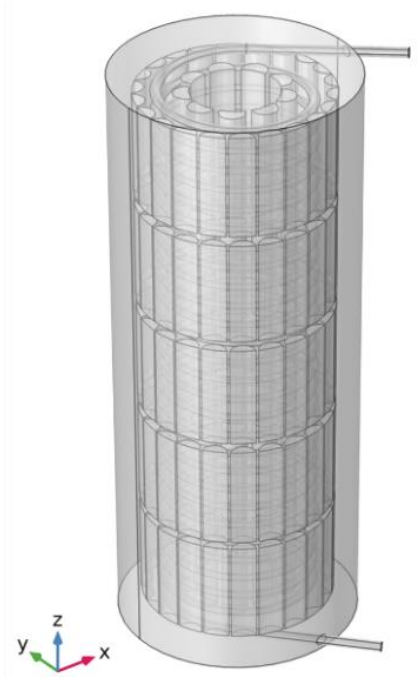

Figure 15. Proposed size and geometry of the PCM prisms within the TES. 
Finally, the all-day simulation of the selected configuration was performed to analyze the effect of PCM amount and geometry changes. Figure 16 shows that the presence of the reduced prisms slightly modified the performance of the TES compared to the case of complete cylinders, which is equivalent to LA_R. Moreover, from 50,000 s, the outlet water temperature is approximately $1{ }^{\circ} \mathrm{C}$ higher than that obtained in WP.

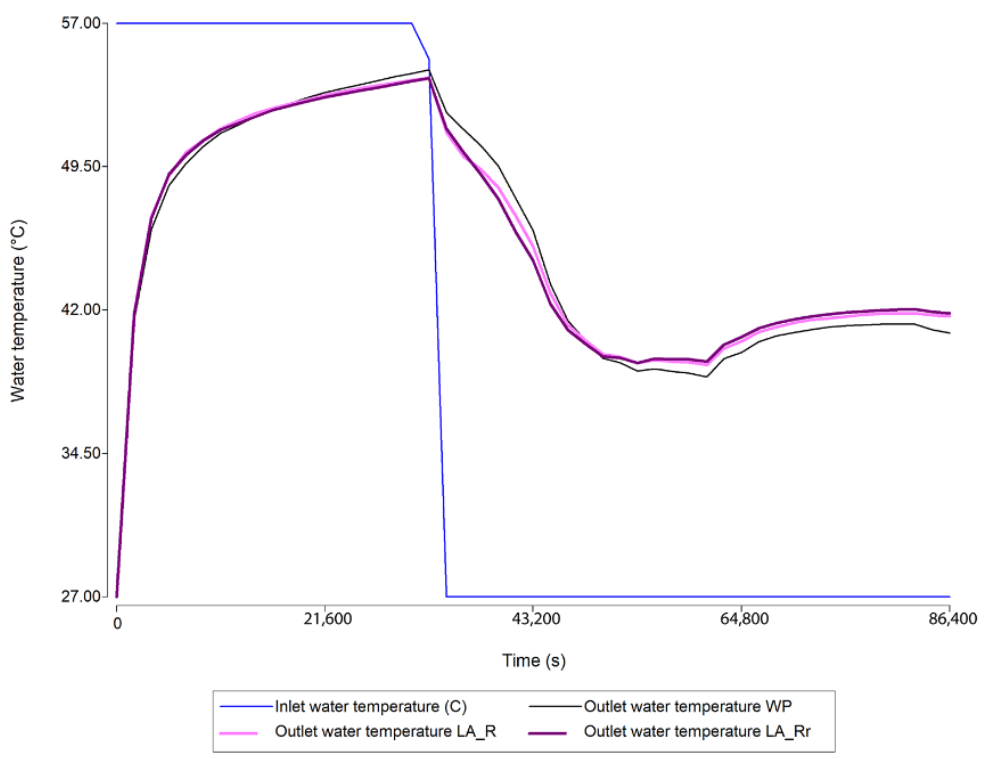

Figure 16. Inlet and outlet water temperatures vs. time to compare the expected behavior of the TES with cylindrical prisms of lauric acid (LA_R), the TES with reduced elements of lauric acid (LA_Rr), and the TES without PCM (WP).

In addition, Table 7 shows that the results obtained for the system with the reduced LA prisms and the original system with lauric acid cylinders are almost the same. However, the LA reduced prisms represent a 50\% reduction in PCM, which means economic savings.

Table 7. Performance comparison between the TES without PCM (WP), the TES with cylindrical prisms of lauric acid (LA_R), and the TES with reduced elements of lauric acid (LA_Rr).

\begin{tabular}{cccc}
\hline Parameter & WP & LA_R & LA_R $\mathbf{R}_{\mathbf{r}}$ (Approx. 50\% Less \\
PCM)
\end{tabular}

Moreover, the WP results are still better in terms of operating hours than the results obtained for LA_R and the LA_Rr. The last changes were not enough to reach the desired minimum outlet water temperature during all the operating hours in any TES. There is not a noticeable difference between systems to justify the addition of PCM due to the additional costs and technical complexity that it represents. 
In the next section, several simulations are presented to evaluate the system's sensibility to the heat transfer properties from the external substance to the PCM, the performance of the sensible heat storage material, with the aim of reaching the proposed targets.

\subsection{Implementation of Step 4: Evaluation of Sensible Heat Storage Substance}

A sensitivity analysis was performed for the proposed LA_ $R_{r}$ by considering the effect of varying the thermal conductivity of a substance with the same sensible heat storage capacity as water $\left(\mathrm{C}_{\mathrm{pw}}=4169.45 \mathrm{~kJ} / \mathrm{m}^{3} \cdot \mathrm{K}\right.$ at $\left.25^{\circ} \mathrm{C}\right)$ [52]. The results of these simultaneous numerical simulations are shown in Figure 17.

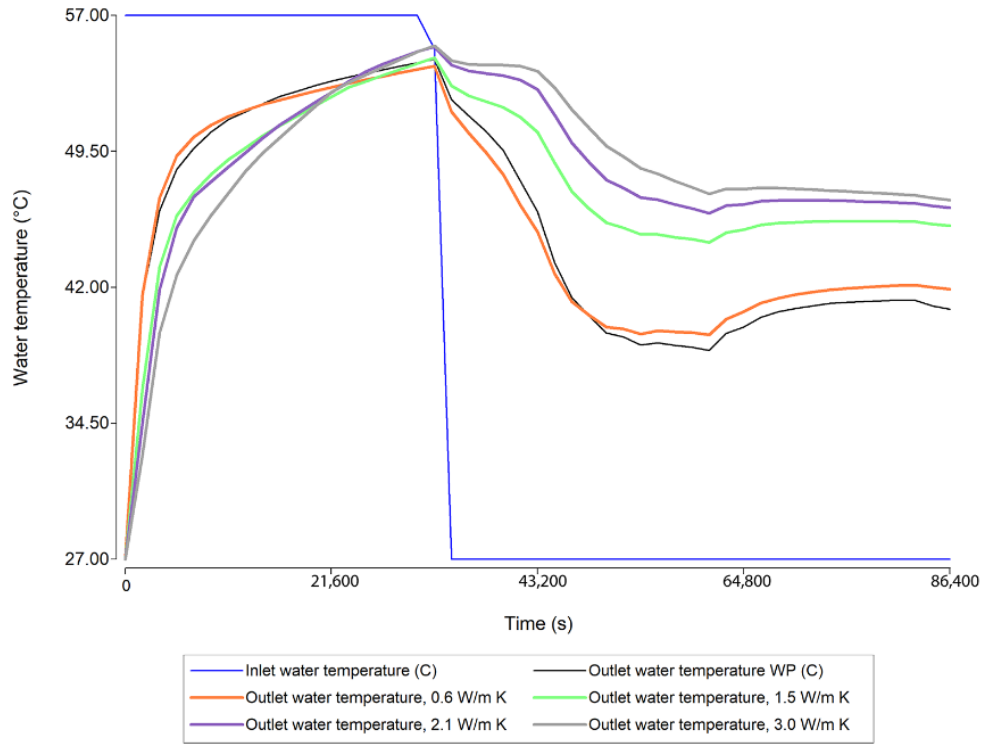

Figure 17. Relation between the water temperature and the external fluid's thermal conductivity variation considering water's constant sensible heat storage capacity in LA_Rr.

Figure 17 showed that increasing the thermal conductivity from $\mathrm{k}=0.6 \mathrm{~W} / \mathrm{m} \cdot \mathrm{K}$ to $\mathrm{k}=3.0 \mathrm{~W} / \mathrm{m} \cdot \mathrm{K}$ increased the ability of the thermal energy storage system to deliver the stored energy during discharging time for the same sensible heat storage capacity. Therefore, this suggested that changing the water for another sensible heat storage substance with higher thermal conductivity and a similar sensible heat storage capacity is a feasible alternative to improve the system's behavior.

Moreover, the accumulated energy during charging time in previous simulations revealed the sensible heat stored was around $50 \%$ of the water's sensible heat storage capacity for a tank volume of $\approx 19 \mathrm{~m}^{3}$, and a temperature difference of $\approx 25{ }^{\circ} \mathrm{C}$ during charging time. Hence, a list of sensible heat storage materials with their main properties as sensible heat storage substances is presented in Table 8 . These materials were selected based on their sensible heat storage capacity, in the range of $0.5 C_{p w}$ to $C_{p w}$.

Table 8. Properties of some identified substances with sensible heat storage capacity in the range of $0.5 \mathrm{C}_{\mathrm{pw}}$ to $\mathrm{C}_{\mathrm{pw}}$.

\begin{tabular}{|c|c|c|c|c|}
\hline Material & $\begin{array}{c}\text { Thermal } \\
\text { Conductivity } \\
(\mathrm{W} / \mathrm{m} \cdot \mathrm{K})\end{array}$ & $\begin{array}{c}\text { Specific } \\
\text { Heat } \\
(\mathrm{kJ} / \mathrm{kg} \cdot \mathrm{K})\end{array}$ & $\begin{array}{l}\text { Density } \\
\left(\mathrm{kg} / \mathrm{m}^{3}\right)\end{array}$ & $\begin{array}{c}\text { Sensible Heat } \\
\text { Storage Capacity } \\
\left(\mathbf{k J} / \mathrm{m}^{3} \cdot \mathrm{K}\right)\end{array}$ \\
\hline Water [52] & 0.623 & 4.182 & 997 & 4169.45 \\
\hline Thermal grease T670 [59] & 3.000 & 1.000 & 2600 & 2600.00 \\
\hline Steatite [60] & 3.300 & 0.980 & 2800 & 2.744 \\
\hline $\begin{array}{l}50 \% \text { Ethylene } \\
\text { Glycol-50\% Water [61] }\end{array}$ & 0.282 & 3.480 & 1075 & 3.741 \\
\hline
\end{tabular}


Table 8 shows that thermal grease and steatite have enough thermal conductivity to present a similar behavior as the curve of $\mathrm{k}=3.0 \mathrm{~W} / \mathrm{m} \cdot \mathrm{K}$, shown in Figure 17. In contrast, the $50 \%$ ethylene glycol $-50 \%$ water mixture has lower thermal conductivity than steatite and thermal grease. Thus, it is not suitable as a medium for the heat transfer between the coil and the reduced prisms.

Thermal greases have a high range of thermal conductivities, and their cost increases as the thermal conductivity increases. High-performance thermal grease with $\mathrm{k}=3.0 \mathrm{~W} / \mathrm{m} \cdot \mathrm{K}$ is an expensive material costing approximately $678 \mathrm{USD} / \mathrm{kg}$ [62]. Another material that has been presented as an alternative is steatite. This material is cheaper compared to thermal grease. It also has wide availability [63]. Therefore, steatite was selected as the chosen sensible heat storage material.

First, the steatite TES performance without PCM (S-WP) was studied by simulating its expected behavior during all the operating time, and maintaining current input. In this study, only the thermal properties of steatite were considered. Figure 18 shows that steatite allowed the outlet water temperature to reach thermal equilibrium with the inlet water temperature at the end of the charging time. In addition, the operating hours increased to $5.5 \mathrm{~h}$. However, the temperature decreased rapidly after 45,000 s.

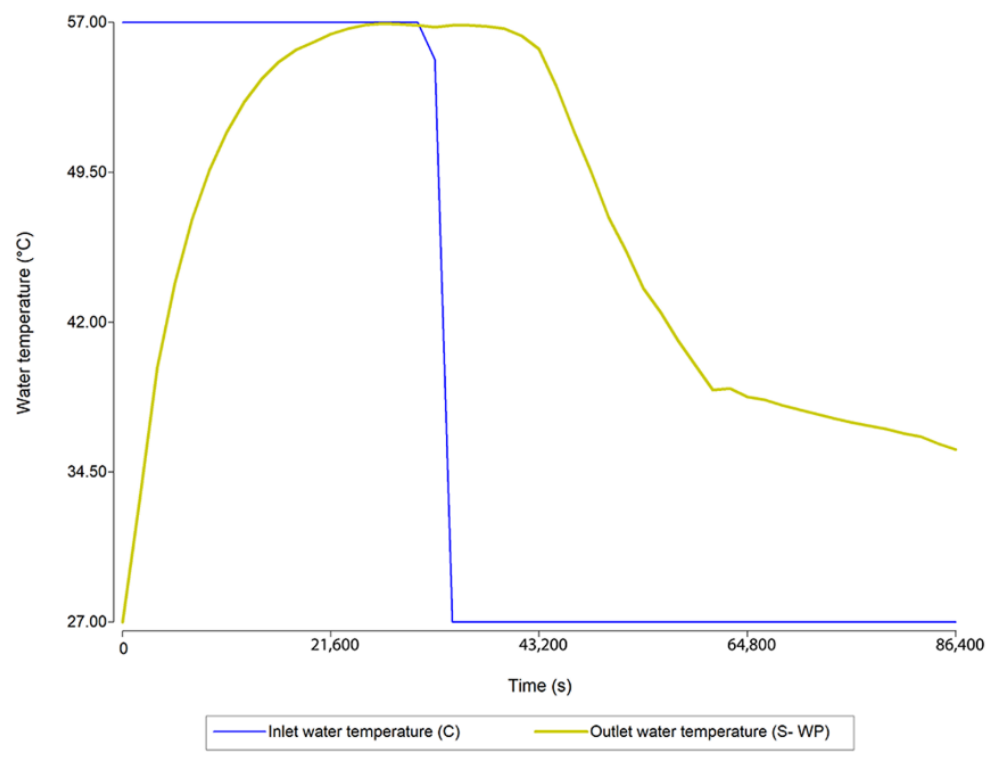

Figure 18. Inlet and outlet water temperatures vs. time for the steatite TES without PCM (S-WP), under current input (C).

Considering the results shown previously in Figure 18, the addition of lauric acid would positively limit the temperature drop. The thermal energy storage with steatite and reduced LA prisms $(S$ LA_R $)$ was simulated for all the operating time. Furthermore, a simulation of a thermal energy storage with steatite and cylindrical LA prisms (S LA_R) was developed to verify the proper shape selection and LA amount suggested in the reduced prisms.

Figure 19 shows that, despite the outlet and inlet water flows did not reach thermal equilibrium, the addition of PCM in S LA_R and S LA_R, mitigated the outlet water temperature drop after $60,000 \mathrm{~s}$. 


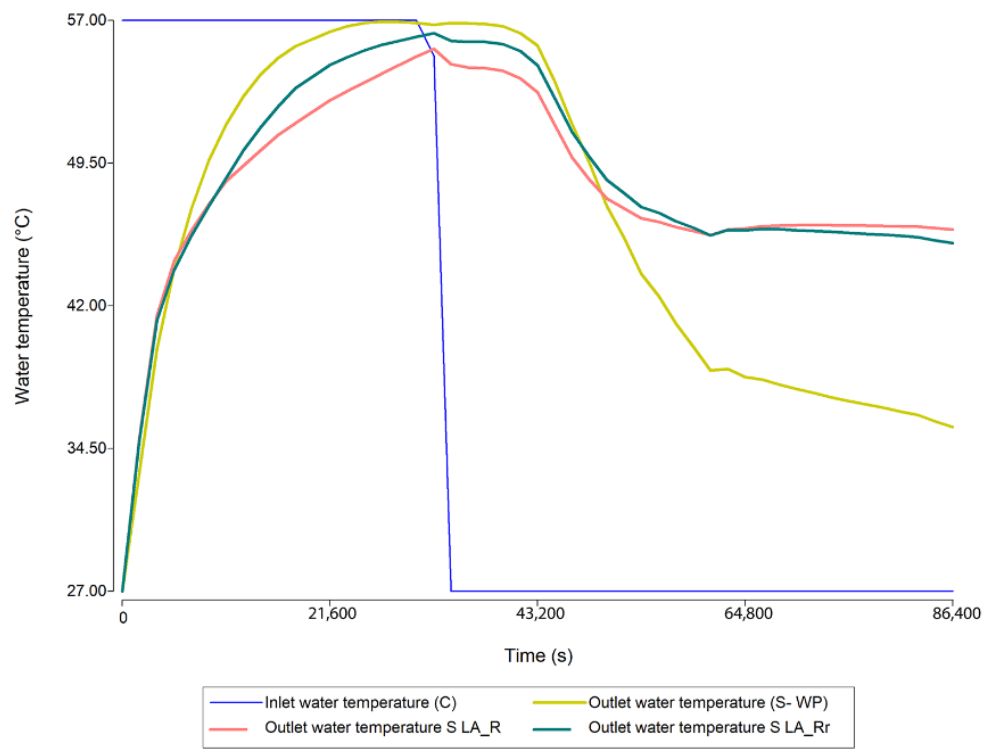

Figure 19. Inlet and outlet water temperatures vs. time curves for the cases of TES with steatite (S), TES with steatite and cylindrical prisms of lauric acid (S LA_R), and a TES with steatite and reduced prisms of lauric acid (S LA_R $)$, under current input (C).

When comparing the effect of the PCM in terms of shape and amount, Figure 19 shows that the S LA_R reached a higher outlet water temperature after charging time than the $S$ LA_R. In addition, it allowed higher outlet water temperatures until 60,000 s, which were the hours of higher demand, as depicted in Figure 3.

Other parameters related to the performance of the studied thermal energy storage systems with steatite as sensible heat storage material are shown in Table 9. It is observed that both TES with steatite and LA reached the desired operating hours, keeping the outlet water temperature above $43^{\circ} \mathrm{C}$. Although S LA_R $\mathrm{R}_{\mathrm{r}}$ accumulated lower energy than the $\mathrm{S}$ LA_R alternative, it could deliver more energy. Therefore, S LA_R $\mathrm{r}$ presented a 10\% higher efficiency while achieving PCM savings of approximately $50 \%$.

Table 9. Performance comparison between a TES with only steatite (S-WP), a TES with steatite and cylindrical prisms of lauric acid (S LA_R), and a TES with steatite and reduced prisms of lauric acid (S LA_R $)$.

\begin{tabular}{cccc}
\hline Parameter & S-WP & S LA_R & S LA_R \\
\hline $\begin{array}{c}\text { Accumulated energy during charging time }(\mathrm{kJ}) \\
\text { Delivered energy during discharging time }(\mathrm{kJ})\end{array}$ & $19,357.12$ & $28,116.01$ & $25,470.68$ \\
$\begin{array}{c}\text { Efficiency (\%) } \\
\text { Maximum outlet water temperature during } \\
\text { charging time }\left({ }^{\circ} \mathrm{C}\right)\end{array}$ & 93.12 & $18,641.70$ & $19,376.85$ \\
$\begin{array}{c}\text { Minimum outlet water temperature during } \\
\text { discharging time }\left({ }^{\circ} \mathrm{C}\right)\end{array}$ & 56.86 & 55.13 & 76.08 \\
$\begin{array}{c}\text { Operating hours (Outlet water temperature over } \\
\left.43^{\circ} \mathrm{C}\right)\end{array}$ & 35.63 & 45.59 & 45.94 \\
\hline
\end{tabular}

A comparison of the increase in performance obtained by applying every step is analyzed graphically in Figure 20. This graph shows that the operating hours were not noticeably impacted by the changes related to the PCM, and WP had the highest number of operating hours until step 3. However, the application of step 4 represented an increase of $750 \%$ in the initial operating hours achieved by $\mathrm{R}$, which means 13 extra hours of hot water with a temperature over $43{ }^{\circ} \mathrm{C}$ for a total of 15 operating hours. 


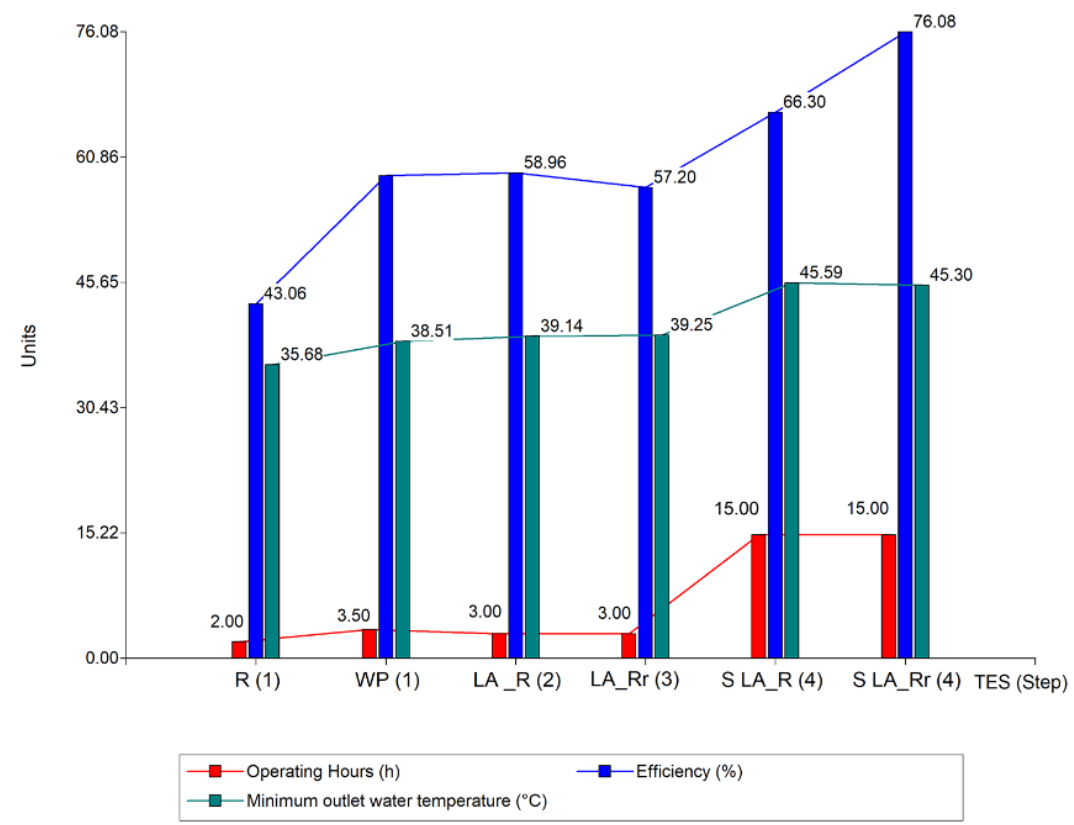

Figure 20. Comparison between performance parameters evaluated in step 1 to step 4 .

The efficiency and minimum outlet water temperature also underwent small changes when applying steps 2 and 3 . The application of step 4 represented an increment of $\approx 10^{\circ} \mathrm{C}$ in the case of the minimum outlet water temperature, and the efficiency increased by $\approx 33 \%$ compared to $\mathrm{R}$, and by $\approx 17.5 \%$ compared to WP. The final proposed redesigned TES (S LA_R ) presented efficiency of $76.08 \%$.

\section{Conclusions and Future Work}

This article presented the conceptualization and implementation of a redesign methodology to enhance an existing TES with PCM system for a SWH while achieving defined operational targets. The proposed four-step redesign methodology was developed based on four improvement opportunities after a critical analysis of a reference TES with PCM. Steps 1 to 3 slightly improved the system performance in terms of the main performance parameters. However, step 4 had the most relevant impact on parameters, such as efficiency, minimum outlet water temperature, and hours of operation. As a result, the system achieved the target operational conditions. The redesigned TES, consisting of steatite as sensible heat storage material and lauric acid as latent heat storage material in reduced prisms (S LA_R ), reached a minimum outlet water temperature of $45.30{ }^{\circ} \mathrm{C}$ and efficiency of $76.08 \%$. In addition, the final redesigned TES showed satisfactory improvements in terms of operational performance when compared to the reference TES with PCM by meeting the two main objectives: an outlet water temperature greater than $43^{\circ} \mathrm{C}$ during discharging time $(15 \mathrm{~h})$ and efficiency greater than $60 \%$ to supply the hot water demand of two families (400 L). These results show the critical role that a suitable redesign methodology can play when improving an existing TES system with PCM for a SWH system.

Future work will involve to extend the proposed methodology and assess the effect of a variable inlet water temperature profile during charging time correlated with the location-specific climatic conditions. Other relevant aspects to consider are the effect of different hot water demands, the performance in continuous operation for more than one day, the impact of turbulent flow, the variations between freezing and melting temperatures of the PCM, the study of the effect of the PCM encapsulation material, and optimization approaches to find the optimal ratio between sensible and latent heat storage materials in the redesigned TES. Finally, experimental tests should be carried out to validate the numerical results presented in this work. 


\begin{abstract}
Author Contributions: Conceptualization, methodology, simulations, and draft preparation, I.A.H.B., review and editing, A.M.J.R., M.D.L.A.O.D.R. and M.Z.S. All authors have read and agreed to the published version of the manuscript.
\end{abstract}

Funding: This research was funded by Secretaría Nacional de Ciencia, Tecnología e Innovación (SENACYT), grant number APY-NI-2019A-21.

Institutional Review Board Statement: Not applicable.

Informed Consent Statement: Not applicable.

Data Availability Statement: Not applicable.

Acknowledgments: The authors acknowledge the full financial support of the Secretaría Nacional de Ciencia, Tecnología e Innovación (SENACYT), and the financial support for Arthur James by The National Research System (In Spanish-Sistema Nacional de Investigación, SNI) from the Government of Panama.

Conflicts of Interest: The authors declare no conflict of interest.

\title{
References
}

1. Kozlova, M. Real option valuation in renewable energy literature: Research focus, trends and design. Renew. Sustain. Energy Rev. 2017, 80, 180-196. [CrossRef]

2. IRENA. Global Renewables Outlook: Energy Transformation 2050; International Renewable Energy Agency: Abu Dhabi, United Arab Emirates, 2020.

3. IRENA. IRENA's Energy Transition Support to Strengthen Climate Action; International Renewable Energy Agency: Abu Dhabi, United Arab Emirates, 2021.

4. Naghavi, M.S.; Ong, K.S.; Badruddin, I.A.; Metselaar, H.S.C.; Mehrali, M.; Akhiani, A.R. Solar hot water production by using latent heat storage under tropical conditions. In Proceedings of the ISES Solar World Congress 2015, Daegu, Korea, 8-12 November 2015; pp. 1-12. [CrossRef]

5. Liu, Z.; Wang, Z.; Ma, C. An experimental study on heat transfer characteristics of heat pipe heat exchanger with latent heat storage. Part I: Charging only and discharging only modes. Energy Convers. Manag. 2006, 47, 944-966. [CrossRef]

6. Khot, S.A.; Sane, N.K.; Gawali, B.S. Thermal Energy Storage using PCM for Solar Domestic Hot Water Systems: A Review. J. Inst. Eng. Ser. C 2012, 93, 171-176. [CrossRef]

7. Naghavi, M.; Metselaar, H.; Ang, B.; Zamiri, G.; Esmailzadeh, A.; Nasiri-Tabrizi, B. A critical assessment on synergistic improvement in PCM based thermal batteries. Renew. Sustain. Energy Rev. 2020, 135, 110259. [CrossRef]

8. Bouhal, T.; El Rhafiki, T.; Kousksou, T.; Jamil, A.; Zeraouli, Y. PCM addition inside solar water heaters: Numerical comparative approach. J. Energy Storage 2018, 19, 232-246. [CrossRef]

9. Abhat, A. Low temperature latent heat thermal energy storage: Heat storage materials. Sol. Energy 1983, 30, 313-333. [CrossRef]

10. Luu, M.T.; Milani, D.; Nomvar, M.; Abbas, A. Dynamic modelling and analysis of a novel latent heat battery in tankless domestic solar water heating. Energy Build. 2017, 152, 227-242. [CrossRef]

11. Carmona, M.; Palacio, M. Thermal modelling of a flat plate solar collector with latent heat storage validated with experimental data in outdoor conditions. Sol. Energy 2018, 177, 620-633. [CrossRef]

12. Wu, W.; Dai, S.; Liu, Z.; Dou, Y.; Hua, J.; Li, M.; Wang, X.; Wang, X. Experimental study on the performance of a novel solar water heating system with and without PCM. Sol. Energy 2018, 171, 604-612. [CrossRef]

13. Bayomy, A.; Davies, S.; Saghir, Z. Domestic Hot Water Storage Tank Utilizing Phase Change Materials (PCMs): Numerical Approach. Energies 2019, 12, 2170. [CrossRef]

14. Kılıçkap, S.; El, E.; Yıldız, C. Investigation of the effect on the efficiency of phase change material placed in solar collector tank. Therm. Sci. Eng. Prog. 2018, 5, 25-31. [CrossRef]

15. Seitov, A.; Akhmetov, B.; Georgiev, A.G.; Kaltayev, A.; Popov, R.K.; Dzhonova-Atanasova, D.B.; Tungatarova, M.S. Numerical simulation of thermal energy storage based on phase change materials. Bulg. Chem. Commun. 2016, 48, 181-188.

16. Işık, S.; Yıldız, C. Improving thermal energy storage efficiency of solar collector tanks by placing phase change materials in novel finned-type cells. Therm. Sci. Eng. Prog. 2020, 19, 100618. [CrossRef]

17. Naghavi, M.; Ang, B.; Rahmanian, B.; Bazri, S.; Mahmoodian, R.; Metselaar, H. On-demand dynamic performance of a thermal battery in tankless domestic solar water heating in the tropical region. Appl. Therm. Eng. 2019, 167, 114790. [CrossRef]

18. Cetina-Quiñones, A.; Xamán, J.; Bassam, A.; Soberanis, M.E.; Perez-Quintana, I. Thermo-economic analysis of a flat solar collector with a phase changing material under tropical climate conditions: Residential and industrial case. Appl. Therm. Eng. 2020, 182, 116082. [CrossRef]

19. Kyriaki, E.; Stergiopoulos, S.; Papadopoulos, A.M. Phase change materials to increase the storage potential of solar thermal systems. In Proceedings of the 2019 4th International Conference on Smart and Sustainable Technologies (SpliTech), Split, Croatia, 18-21 June 2019; pp. 1-7. [CrossRef] 
20. Zhao, J.; Ji, Y.; Yuan, Y.; Zhang, Z.; Lu, J. Energy-Saving Analysis of Solar Heating System with PCM Storage Tank. Energies 2018, 11, 237. [CrossRef]

21. Ge, H.; Li, H.; Mei, S.; Liu, J. Low melting point liquid metal as a new class of phase change material: An emerging frontier in energy area. Renew. Sustain. Energy Rev. 2013, 21, 331-346. [CrossRef]

22. Kanimozhi, B.; Bapu, B.R.; Pranesh, V. Thermal energy storage system operating with phase change materials for solar water heating applications: DOE modelling. Appl. Therm. Eng. 2017, 123, 614-624. [CrossRef]

23. Badiei, Z.; Eslami, M.; Jafarpur, K. Performance improvements in solar flat plate collectors by integrating with phase change materials and fins: A CFD modeling. Energy 2019, 192, 116719. [CrossRef]

24. Addad, Y.; Abutayeh, M.; Abu-Nada, E. Effects of Nanofluids on the Performance of a PCM-Based Thermal Energy Storage System. J. Energy Eng. 2017, 143, 04017006. [CrossRef]

25. Kumar, P.M.; Mylsamy, K. A comprehensive study on thermal storage characteristics of nano-CeO ${ }_{2}$ embedded phase change material and its influence on the performance of evacuated tube solar water heater. Renew. Energy 2020, 162, 662-676. [CrossRef]

26. Kee, S.Y.; Munusamy, Y.; Ong, K.S. Review of solar water heaters incorporating solid-liquid organic phase change materials as thermal storage. Appl. Therm. Eng. 2017, 131, 455-471. [CrossRef]

27. Mofijur, M.; Mahlia, T.M.I.; Silitonga, A.S.; Ong, H.C.; Silakhori, M.; Hasan, M.H.; Putra, N.; Rahman, S.M.A. Phase Change Materials (PCM) for Solar Energy Usages and Storage: An Overview. Energies 2019, 12, 3167. [CrossRef]

28. Fairey, P.; Parker, D. A Review of Hot Water Draw Profiles Used in Performance Analysis of Residential Domestic Hot Water Systems. Fla. Sol. Energy Cent. 2004, 2, 8.

29. ASME. Performance Requirements for Water Temperature Limiting Devices 2020. Available online: https://www plumbingfoundation.nyc/wp-content/uploads/2014/10/Summary-Plumbing-Code.Dec_.31.2014.pdf (accessed on 19 September 2021).

30. Padovan, R.; Manzan, M. Development of a stratified tank storage component for ESP-r with embedded phase change material modules. Proc. Inst. Mech. Eng. Part A J. Power Energy 2013, 1, 56-61. [CrossRef]

31. Porteiro, J.; Míguez, J.L.; Crespo, B.; De Lara, J.; Pousada, J.M. On the Behavior of Different PCMs in a Hot Water Storage Tank against Thermal Demands. Materials 2016, 9, 213. [CrossRef] [PubMed]

32. Haillot, D.; Franquet, E.; Gibout, S.; Bédécarrats, J.-P. Optimization of solar DHW system including PCM media. Appl. Energy 2012, 109, 470-475. [CrossRef]

33. Padovan, R.; Manzan, M. Genetic optimization of a PCM enhanced storage tank for Solar Domestic Hot Water Systems. Sol. Energy 2014, 103, 563-573. [CrossRef]

34. Patel, J.R.; Joshi, V.; Rathod, M.K. Thermal performance investigations of the melting and solidification in differently shaped macro-capsules saturated with phase change material. J. Energy Storage 2020, 31, 101635. [CrossRef]

35. Pizzolato, A.; Sharma, A.; Maute, K.; Sciacovelli, A.; Verda, V. Design of effective fins for fast PCM melting and solidification in shell-and-tube latent heat thermal energy storage through topology optimization. Appl. Energy 2017, 208, 210-227. [CrossRef]

36. Fernandez, A.I.; Martínez, M.; Segarra, M.; Martorell, I.; Cabeza, L.F. Selection of materials with potential in sensible thermal energy storage. Sol. Energy Mater. Sol. Cells 2010, 94, 1723-1729. [CrossRef]

37. Hussein, A.; Abd-Elhady, M.S.; El-Sheikh, M.N.; El-Metwally, H.T. Improving Heat Transfer Through Paraffin Wax, by Using Fins and Metallic Strips. Arab. J. Sci. Eng. 2017, 43, 4433-4441. [CrossRef]

38. Harris, I.; Rosario, M.D.L.Á.O.D.; James, A.; Bruneau, D. Introduction to the application of phase change materials under tropical climate of Panama. In Proceedings of the 2019 7th International Engineering, Sciences and Technology Conference (IESTEC), Panama, Panama, 9-11 October 2019; pp. 177-182. [CrossRef]

39. Termosolar Panamá. Análisis del Potencial de Desarrollo del Mercado de Calentadores Solares de Agua en Panamá; Termosolar Panamá: Clayton, Panama, 2019.

40. Rozanna, D.; Chuah, T.G.; Salmiah, A.; Choong, T.S.Y.; Sa'ari, M. Fatty Acids as Phase Change Materials (PCMs) for Thermal Energy Storage: A Review. Int. J. Green Energy 2005, 1, 495-513. [CrossRef]

41. Zuo, J.; Li, W.; Weng, L. Thermal properties of lauric acid/1-tetradecanol binary system for energy storage. Appl. Therm. Eng. 2011, 31, 1352-1355. [CrossRef]

42. Bayram, U.; Aksöz, S.; Maraşl1, N. Temperature dependency of thermal conductivity of solid phases for fatty acids. J. Therm. Anal. 2014, 118, 311-321. [CrossRef]

43. RubiTherm. Datasheet RT44HC. 9 October 2020. Available online: https:/ /www.rubitherm.eu/media/products /datasheets/ Techdata_-RT44HC_EN_09102020.PDF (accessed on 12 August 2021).

44. Axiotherm. Datasheet ATP43. 2018. Available online: www.axiotherm.de (accessed on 12 August 2021)

45. Gadhave, P.; Prabhune, C.; Pathan, F. Selection of Phase Change Material for Domestic Water Heating Using Multi Criteria Decision Approach. Aust. J. Mech. Eng. 2020, 1-21. [CrossRef]

46. Martínez-Gómez, J.; Urresta, E.; Gaona, D.; Guerrón, G. Selection of Phase Change Materials for Latent Heat Storage. Revista Técnica Energía 2017, 13. [CrossRef]

47. Kumar, R.; Jagadish; Ray, A. Selection of Material for Optimal Design Using Multi-criteria Decision Making. Procedia Mater. Sci. 2014, 6, 590-596. [CrossRef]

48. Ebadi, S.; Tasnim, S.H.; Aliabadi, A.A.; Mahmud, S. Melting of nano-PCM inside a cylindrical thermal energy storage system: Numerical study with experimental verification. Energy Convers. Manag. 2018, 166, 241-259. [CrossRef] 
49. Dzikevics, M.; Ansone, A.; Blumberga, D. Modelling of Phase Change in Spheres for Applications in Solar Thermal Heat Storage Systems. Energy Procedia 2016, 95, 112-118. [CrossRef]

50. Abokersh, M.H.; Osman, M.; El-Baz, O.; El-Morsi, M.; Sharaf, O. Review of the phase change material (PCM) usage for solar domestic water heating systems (SDWHS). Int. J. Energy Res. 2017, 42, 329-357. [CrossRef]

51. Alwaeli, A.H.A.; Kazem, H.A.; Chaichan, M.T.; Sopian, K. Experimental investigation of using nano-PCM/nanofluid on a photovoltaic thermal system (PVT): Technical and economic study. Therm. Sci. Eng. Prog. 2019, 11, 213-230. [CrossRef]

52. IAPWS. Revised Release on the IAPWS Formulation 1995 for the Thermodynamic Properties of Ordinary Water Substance for General and Scientific Use. 2018. Available online: http:/ / iapws.org/relguide/IAPWS95-2018.pdf (accessed on 9 November 2021).

53. Bird, R.B.; Stewart, W.E.; Lightfoot, E. Transport Phenomena, 2nd ed.; John Willey \& Sons, Inc.: Hoboken, NJ, USA, 2002.

54. He, B.; Martin, V.; Setterwall, F. Phase transition temperature ranges and storage density of paraffin wax phase change materials. Energy 2004, 29, 1785-1804. [CrossRef]

55. Hu, T.; Li, Y.; Su, D.; Lv, H.X. Thermal Modeling Solid-Liquid Phase Change Materials (PCMs). Adv. Mater. Res. 2013, 746, 161-166. [CrossRef]

56. COMSOL. Controlling the Time Dependent Solver Timesteps-Knowledge Base 2021. Available online: https://www.comsol. com/support/knowledgebase/1254 (accessed on 28 December 2021).

57. Ray, A.K.; Rakshit, D.; Kumar, K.R.; Gurgenci, H. A Comparative Study of High-Temperature Latent Heat Storage Systems. Energies 2021, 14, 6886. [CrossRef]

58. COMSOL. How to Inspect Your Mesh in COMSOL Multiphysics®COMSOL. 2017. Available online: https://www.comsol.com/ blogs/how-to-inspect-your-mesh-in-comsol-multiphysics/ (accessed on 12 May 2017).

59. PARKER Chomerics. Thermal Grease T650-T660-T670 Datasheet. 2021. Available online: https:/ / www.parker.com/Literature/ Chomerics/Catalogs/Thermal\%20Grease\%20T650-T660-T670.pdf (accessed on 19 September 2021).

60. GNPGraystar. Thermal Properties of Ceramics. 2021. Available online: https://gnpgraystar.com/wp-content/uploads/2020/05/ ThermalPropertiesofCeramicsGraphic.pdf (accessed on 19 September 2021).

61. Islam, M.R.; Shabani, B.; Rosengarten, G. Electrical and Thermal Conductivities of 50/50 Water-ethylene Glycol Based TiO 2 Nanofluids to be Used as Coolants in PEM Fuel Cells. Energy Procedia 2017, 110, 101-108. [CrossRef]

62. Digi-Key Electronics. 65-00-T670-00014. 2021. Available online: https://www.digikey.es/product-detail/en/parker-chomerics/ 65-00-T670-00014/1944-1127-ND/9350016 (accessed on 3 October 2021).

63. Jidhesh, P.; Arjunan, T.; Rathnaraj, J.D. Experimental investigation on heat transfer characteristics of phase change composite for thermal energy storage system. Mater. Today Proc. 2020, 42, 618-625. [CrossRef] 